INTERNATIONAL JOURNAL OF

SYSTEMATIC BACTERIOLOGY

Vol. 19, No. 2

April 1969

pp. $165-166$

Copyright 1969, Iowa State University Press

\title{
DESIGNATION OF THE TYPE STRAIN OF BACTEROIDES CORRODENS EIKEN 1958
}

S. D. Henriksen

Kaptein W. Wilhelmsen og Frues Bakteriologiske Institutt University of Oslo, Rikshospitalet, Oslo, Norway

ABSTRACT. The strain 333/54-55, a facultatively anaerobic strain from the collection studied by Eiken, is designated as the type strain of Bacteroides corrodens. The strain has been deposited in the National Collection of Type Cultures and in the American Type Culture Collection.

In 1958 Eiken (1) described a Gram-negative rod which could frequently be isolated from pus from actinomycotic abscesses and from other clinical material by anaerobic culture. The organism was characterized by growing with depressed, "corroding" colonies. Some strains were strict anaerobes, other s could be adapted to aerobic growth. A few other authors have also described this organism $(2,3,5$, 6). Eiken did not designate a type strain of the species. In a paper, which is being published elsewhere (4), it is proposed that the strain 333/54-55, a facultatively anaerobic strain from the collection studied by Eiken should be designated as the type strain of the species Bacteroides corrodens Eiken 1958. The strain has been deposited in the National Collection of Type Cultures, London, and in the American Type Culture Collection, Rockville, Maryland.

\section{REFERENCES}

1. Eiken, M. 1958. Studies on an anaerobic, rod-shaped gram-negative microorganism: Bacteroides corrodens n. sp. Acta Path. et Microbiol. Scand. 43:40 4-416.

2. - 1960. Unders $\not g$ gelser over Bacteroides corrodens. Thesis, Copenhagen.

3. Henriksen, S. D. 1948. Studies in gram-negative anaerobes II. Gram-negative anaerobes with spreading colonies. Acta Path, et Microbiol. Scand, 25:368375. 
4. 1969. Corroding bacteria from the respiratory tract. II. Bacteroides corrodens. Acta Path. et Microbiol. Scand. 75:91-96.

5. Khairat, O. 1967. Bacteroides corrodens isolated from bacteriaemias. I. Path. Bact. 95:29-40.

6. Reinhold, L. 1966. Unter suchungen an Bacteroides corrodens (Eiken 1958). Zentralbl. Bakt. Abt.I Orig. 201: $49-57$. 